\title{
Biosorption of Malachite Green Dye from Wastewater with Henfeathers -Analysis of Various Mathematical Models Wrt Continuous Adsorption
}

\author{
K.S.G.V. Manikrishna, Veluru Sridevi, Sri Himaja Pamu, M.Tukaram Bai, K.S.NV. Prasad
}

\begin{abstract}
In recent years, the remediation of hazardous organic dye-contaminated aquatic habitats has been a key research priority for environmental and chemical engineers. The goal of this research was to see how well malachite green adsorbs from waste water in a continuous column system having fixed bed. A biosorbent made from waste materials such as hen feathers has been shown to extract the water-soluble malachite green colour from waste water. The adsorption potential of malachite green dye ions in a continuous flow adsorption column is investigated in this work. The hen feathers' performance in the fixed bed column was assessed under a variety of operating circumstances, including bed height in the range $6-10 \mathrm{~cm}$; flow in the range $4-12 \mathrm{ml} / \mathrm{min}$, and starting concentration (10-30 mg/l). In comparison to other testing settings, the bed height $(8 \mathrm{~cm})$, flowrate $(12 \mathrm{ml} / \mathrm{min})$, and maximum input concentration $(20 \mathrm{mg} / \mathrm{l})$ resulted in the highest malachite green absorption of $2.829 \mathrm{mg} / \mathrm{g}$. The column experimental data collected under various conditions was evaluated using three distinct models namely 1. Bohart-Adams model, 2 Yoon-Nelsons model, and 3 BDST model, all of which produced a decent estimation of the breakthrough curve. The findings from the Yoon-nelson and BDST models, on the other hand, were more favourable. The several characteristics of the hen feathers were studied using FTIR studies. The activated hen feather powder was a successful potential bio sorbent for the malachite green from aqueous phase.
\end{abstract}

Keywords: pH, Adsorption, Hen feathers, Dye, Breakthrough curve, fixed bed column
Manuscript received on July 27, 2021.

Revised Manuscript received on August 10, 2021.

Manuscript published on August 30, 2021.

* Correspondence Author

K.S.G.V. Manikrishna*, M Tech Scholar, Department of Chemical Engineering, College of Engineering, Andhra University, Visakhapatnam. Email: manikrishnakanda@gmail

Veluru Sridevi, Professor, Department of Chemical Engineering, College of Engineering, Andhra University, Visakhapatnam. Email: velurusridevi@yahoo.co.in

Sri Himaja Pamu, Mtech Scholar, Department of Chemical Engineering, College of Engineering, Andhra University, Visakhapatnam. Email: u.mehimaja@gmail.com

M.Tukaram Bai, Professor, Department of Chemical Engineering, College of Engineering, Andhra University, Visakhapatnam. Email: tukarambai@rediffmail.com

K.S.NV. Prasad, PHD Scholar, Department of Chemical Engineering College of Engineering, Andhra University, Visakhapatnam. Email: ksvnkumari@gmail.com

(c) The Authors. Published by Blue Eyes Intelligence Engineering and Sciences Publication (BEIESP). This is an open access article under the CC BY-NC-ND license (http://creativecommons.org/licenses/by-nc-nd/4.0/)

\section{INTRODUCTION}

$D_{\text {yes are more stable and harder to remove from }}$ effluents owing to their complicated aromatic molecular constitution and artificial foundation. More than 10,000 dyes are commercially available today. Industries like Textile industry, pulp and paper industry, rubber industry, various plastic manufacturing industries, leather industry, cosmetics industry, pharmaceutical industry,food industry etc all utilise dyes[1]. The dye industry dumps a large amount of dye effluent into the aquatic environment. Because the effluent is harmful to aquatic life, it must be treated before being discharged into the system. It also can't be utilised as a source of water without first being treated. Dyeing organic compounds allows for the vibrant coloration of fibre and a few other materials. Natural dyes and artificial dyes are the two types of dyes. They are classified into various types namely azo, anthraquinone, phthalocyanine, aromatic, nitro dyes etc based on their molecular structure. Acidic, basic, sulphur, reactive, dispersion, direct dyes etc are divisions depending on application methods. Animals, plants, and minerals are used to make natural dyes.As per the natural availability, they are be classified into: 1 . Plant dyes, which are made from the root or the stem or the leaf or the fruit of certain plants,(Example: indigo) which is made using the leaves of the indigo plant. A chemical, Curcumin is produced from haldi; A chemical, alizarin is prepared using madder. Animal dyes are the colours derived from the body of an animal; Mineral dyes are dyes made from coloured non-organic minerals and other manganese-based minerals. Synthetic dyes are produced primarily by the chemical operation of pitch fractionated products. Because of its affect on the immunological and reproduction systems, MG has lately emerged as a significant environmental concern $[2,3,4]$. Due to the toxic properties of MG and its derivaties, discharging MG-containing waste water into the normal water bodies decrease light diffusion into the water resources and may cause damage to the life of living things in them. $[5,6,7]$. MG is harmful to all the mammals, and it is proved to cause cancer to the liver and also disorders of thyroid, in animals which are employed for experiments. Several traditional techniques, including oxidation, coagulation, precipitation, ozonation, and adsorption, were used to treat these wastewaters [8].

Published By:

Blue Eyes Intelligence Engineering and Sciences Publication

(C) Copyright: All rights reserved. 


\section{Biosorption of Malachite Green Dye from Wastewater with Henfeathers -Analysis of Various Mathematical Models Wrt Continuous Adsorption}

Adsorption has been shown to be extremely efficient and simple $[9,10]$ due to its ease of application and availability of a wide variety of adsorbents. Because of its low cost and lack of pre-treatment requirements, the use of naturally accessible biomass as bio sorbents has grown in favour in recent years. Our team recently investigated the usage of the hen feather as a bio sorbent to eliminate the toxic triphenyl methane, Brilliant FCF and discovered that it was both effective and cost-effective. There isn't much literature on using chicken feathers as an adsorbent. There were just a few reports available, all of which focused on the removal of metal contaminants from wastewater [11-14]. As a result, the notion of using hen feather as a biosorbent to eliminate harmful dyes appears to be a novel one for the suitable, beneficial, and necessary use of such a waste item for mankind. The current goal of the study is to see if the bio sorbent can be used effectively in a continuous column system. The impact of various operating factors namely bed's depth, flow rate of the feed, input concentration of MG has been investigated. To explain the breakthrough curves, the experimental observations was fitted to several models.

\section{MATERIALS \& METHODS}

A. Preparation of the Biosorbent: The $1 \mathrm{~cm}$ long hen feathers were neatly cleaned using double distilled water before drying. The delicate barb from each dried hen feather the hard rachis in the centre was removed and discarded. The organic substance that had attached to the barbs was then oxidised by treating them with peroxide (30 percent v/v) for around 24 hours. After that, the fabric was dried in a vacuum desiccator for 12 hours at $60^{\circ} \mathrm{C}$.

B. Characteristics of the Biosorbent: The bio sorbent was characterised using a spectrum GX spectrophotometer having a resolution of $1 \mathrm{~cm}$ and 4 scans with background range from 400 to $4000 \mathrm{~cm}$. The peaks were identified by comparing the spectra to those described in the literature.

C. Preparation of the malachite green source solution: A $1000 \mathrm{mg} / \mathrm{L}$ source solution of Malachite green is prepared using 1 gram of dye in a $1000 \mathrm{ml}$ round bottom flask containing double distilled water. This solution is used as a stock solution source. Synthetic samples of various dye intensities were generated from this stock solution using suitable dilutions. $20 \mathrm{mg} / \mathrm{L}$ stock solution is made by diluting 20 milliliter of 1000 PPM source solution in a $1000 \mathrm{~mL}$ vol flask with distilled water till the mark. The $\mathrm{pH}$ is set to the desired level with the help of HCL $(0.1 \mathrm{~N})$ and $\mathrm{NaOH}(0.1 \mathrm{~N})$. A UV spectrophotometer Systronics at a $\lambda \max =617 \mathrm{~nm}$ is used to examine the dye solutions that have been prepared.

D. For fixed bed: The glass column with a 3 centi metre internal dia and a $20 \mathrm{~cm}$ height is used for the fixed bed tests. Height of the bed, flow rate \& initial concentration of MG were chosen as the study's parameters. Glass wool is put at the entrance and outflow of the column to prevent any unnecessary removal of the bio sorbent. The malachite green sol.is supplied at the open end of the glass column with the help of a roller-pump. The outlet liquid is collected at regular interval of time at the bottom of the glass column for our analysis. The flow rate was monitored on a regular basis, and pumping was continued until no more malachite green biosorption occurred, i.e., the intake and exit concentrations of malachite green were equal. Table I shows the conditions is chopped into little pieces of around $0.1 \mathrm{~mm}$ in length, and

of the Glass column regarding the biosorption of MG on activated hen feathers

Table-1: Glass Column's Experiment Parameters during the Adsorption of MG on Activated Hen Feathers

\begin{tabular}{|c|c|c|}
\hline $\begin{array}{c}\text { Initial conc of } \\
\text { MG (mg/l) }\end{array}$ & $\begin{array}{c}\text { Bed height } \\
(\mathbf{c m})\end{array}$ & $\begin{array}{c}\text { Flow rate } \\
\text { (ml/min) }\end{array}$ \\
\hline 10 & 8 & 8 \\
20 & $6,8,10$ & $4,8,12$ \\
30 & 8 & 12 \\
\hline
\end{tabular}

E. BTC \& MTZ: The shape of the BTC has been properly calculated in order to build a firm and fast bed column and, as a result, the appearance of the breakpoint, which is critical for determining the practicality of utilizing the biosorbent in real-world conditions. Wrt a particular column bed's height, BTC is defined as the graph between exit concentration and time delay or volume throughput reacted [15]. The presentation of a packed bed may be got using BTC. Due to various factors such as intake rate of flow, initial adsorbate dosage \& other features like as column dimensions and bed's depth, the BTC's distinctive form along the time axis changes. As a result, efficient adsorption column design necessitates using BTC to forecast the concentration-time profile of the effluent released from the column. The typical Break Through Curve (BTC) is calculated from graph plotted between Concentration of effluent/influent (Ct) or $\mathrm{C}$ effluent (Co) and treated volume (V) or time (t) for a particular bed's height. The optimal BTC, according to Ghorai and Pant, is one in which the column capacity is completely exhausted [16]. The concentration at the the turning point which is also known as break through point, $\mathrm{Cb}$, is selected at random. The adsorbent is regarded basically depleted when the effluent's concentration $\mathrm{Ct}$ approaches 99.5 percent of Co intital concentration $[17,18]$. The total quantity of absorbed adsorbate is determined by the area under the BTC for a particular feed concentration. The following parameter calculations apply to column data analysis. $\mathrm{T}$ he time equivalent to total capacity is given by: [19]:

$t_{t}=\int_{t=0}^{t=m}\left(1-\frac{c_{t}}{c_{0}}\right) d t=A_{1}+A_{2}$

The Time equivalent to practical capacity is:

$t_{u}=\int_{t=0}^{t_{b}}\left(1-\frac{c_{t}}{c_{0}}\right) d t=A_{1}$

The underutilised bed height is calculated using the bed's usable capacity up until the breakthrough time point. $t_{u}$ $\approx t_{b}$

The value of $t_{t}$ (total time) is given by area under the curve $\int_{t=0}^{t=0}\left(1-\frac{c_{t}}{c_{0}}\right) d t$, where the area of the curve $\int_{t=0}^{t_{b}}\left(1-\frac{c_{t}}{c_{0}}\right) d t$ indicate the $t_{u}$ value. $t_{u} / t_{t}$ which is the capacity of total bed used upto the break point. The area which is under this curve can be computed both visually and numerically. At the front of the glass column, a MTZ is created wherein biosorption occurs.

Published By:

Blue Eyes Intelligence Engineering

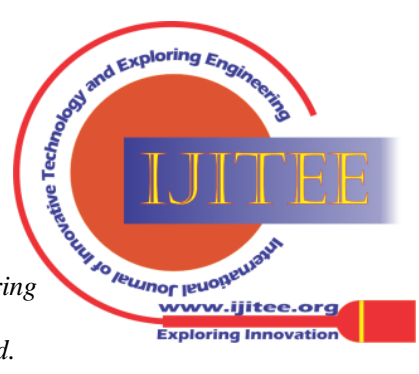


The nature of the given biosorbate, the properties of the given biosorbent, the mass of the adsorber, the particle dimensions of the adsorbent, the adsorbate initial concentration, $\mathrm{pH}$ of solution, and rate of flow of solution are all regulating variables for the depth of MTZ [20]. The lifespan of the column is significantly affected by bed height, solute concentration, and flow rate [21]. The Mass Transfer Zone (MTZ) is caliberated as

$H_{\text {UNB }}=\left(1-\frac{t_{u}}{t_{\mathrm{t}}}\right) H_{T}=\left(1-\frac{t_{b}}{t_{\mathrm{t}}}\right) H_{T}$

here $H_{T}$ is total height of the bed in $\mathrm{cm}$ MTZ $=H_{\text {UNE }}$

The used bed length $H_{B}$ can be calculated as

$H_{B}=\left(\frac{t_{b}}{t_{t}}\right) H_{T}$

The volume of the stream of effluent, $V_{\text {eff }}(\mathrm{mL})$ :

$V_{\text {eff }}=Q t_{\text {total }}$

Wherein Q represents the rate of volumetric flow in $\mathrm{mL} / \mathrm{min}$ $t_{\text {total }}$ represents the total time of flow in min.

The amount of total dye adsorbed, $q_{\text {total }}$ measured in mg, can be computed from the area under the given breakthrough curve:

$q_{\text {total }}=\frac{Q}{1000} \int_{t=0}^{t=\text { total }} C_{\text {add }} d t$

where $C_{\text {ad }}$ is the dye removal concentration in $\mathrm{mg} / \mathrm{l}$.

Equilibrium dye uptake of the column, $q_{\text {e exp }},(\mathrm{mg} / \mathrm{g})$, in the glass column :

$q_{\text {e.exp }}=\frac{q_{\text {total }}}{\mathrm{m}}$

where in $\mathrm{m}$ represents the weight of the given dry adsorbent in the column (g).

Total metal ion which is entering the column ( $\left.m_{\text {total }}\right)$ is computed from the equation below

$m_{\text {total }}=\frac{C_{0} Q t_{\text {total }}}{1000}$

and the removal \% of MG is

$\mathrm{Y}(\%)=\frac{q_{\text {total }}}{\mathrm{m}_{\text {total }}} * 100$

\section{F. Breakthrough curve modelling}

To construct the adsorption column, an estimation of the concentration vs time profile from the break through curve of the discharged effluent from the column is necessary. The primary characteristics that affect the operations and dynamic responsiveness of adsorption in a plug flow system are the breakthrough time and curve shape (or slope). The experimental data was analysed using the Bohart-Adams, BDST, and Yoon-Nelson equations.

Bohart-Adams model: The surface reaction theory was used to develop the Bohart-Adams model [22], which approximates that the equilibrium is not immediate. As a result, rate of adsorption is related to adsorbent residual capacity and adsorbate concentration. This model [23] describes the connection between and $t$, in a plug flow arrangement for chlorine adsorption using an activated charcoal. The relationship between time and column bed depth, represented asln $\frac{C_{2}}{C_{1}}=k_{A B} C_{1} t-k_{A B} N_{0} \frac{z}{v_{0}}$

where $k_{A B}$ is the Bohart-Adams kinetic coefficient in $\mathrm{L} / \mathrm{mg} / \mathrm{min}$

\section{$N_{0}$ - Saturation concentration (mg/l)}

\section{$U_{0}$ - Superficial velocity $(\mathrm{cm} / \mathrm{min})$}

z - bed's depth (cm)

The Yoon-Nelson Model: Yoon and Nelson (1984) created another model for assessing the breakthrough performance of the column. The model is dependent on the approximation that for each adsorbate particle, the decreasing rate of adsorption is proportional to adsorbate adsorption as well as adsorbate breakthrough on the adsorbents [24]. The Yoon-Nelson model does not require any elaborate specifications or data regarding adsorbate qualities, adsorbent type, or physical properties. It is provided byln $\left(\frac{C_{2}}{C_{1}-C_{2}}\right)=k_{Y N} t-\tau k_{Y N}$

Here $k_{Y N}$ is known as the rate constant $\left(\min ^{-1}\right)$

$\tau$ represents the time needed for 50 percent of breakthrough of adsorbate (mins)

BDST model: This simple and easy technique predicts the break through info in terms of bed's depth as well as service duration. This model posits that adsorption is regulated by a reaction among the biosorbate and unutilized biosorbent as a function of the time of contact. The value of NO adsorption capacity and Ka are obtained from a linear graph of height ( $\mathrm{Z}$ in $\mathrm{cm}$ ) and time ( $\mathrm{t}$ in min) (rate constant). The BDST model's broad relationship is shown below. [25].

$$
t=\frac{N_{0} z}{C_{1} w}-\frac{1}{k C_{1}} \ln \left(\frac{C_{1}}{C_{2}}-1\right)
$$

Where $\mathrm{c}_{1}$ and $\mathrm{C}_{2}$ represent the input and outlet concentrations, $\mathrm{k}$ represents the adsorption rate constant (l/mg min) \&No represents capacity of the adsorption (mg/l), respectively. The bed's depth (in $\mathrm{cm}$ ) is $\mathrm{z}$, and the service time to breakthrough is t. (min).

The parameters of the dynamic adsorption model were determined using linear regression to match the three models to experimental data. Coefficient evaluation(R2) and identification of error were accessed to assess the superiority or suitability of each model.

The influence of various factors on Malachite Green adsorption was first visually studied, and then a theoretical attempt was made to validate the observation derived from the graphical analysis.

\section{RESULTS AND DISCUSSIONS}

\section{A. Characterization of Hen feathers}

\section{Fourier Transform Infra-Red Spectroscopy (FTIR)}

Infrared spectroscopy is a type of molecular vibration spectroscopy that is molecule-specific and provides direct information on functional groups, their interactions, and their orientations. Its sample criteria enable the collection of data from liquids/gases, as well as solid surfaces in particular. The identification of the functional groups involved in dye sorption is made possible by band shifts and variations in signal strength.

Published By:

Blue Eyes Intelligence Engineering and Sciences Publication

(C) Copyright: All rights reserved.

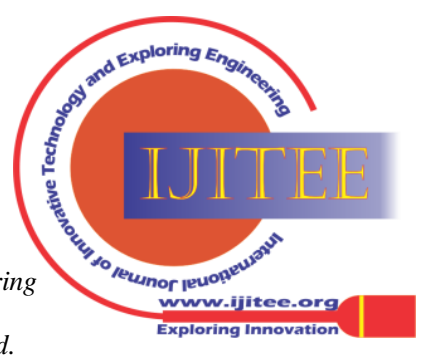




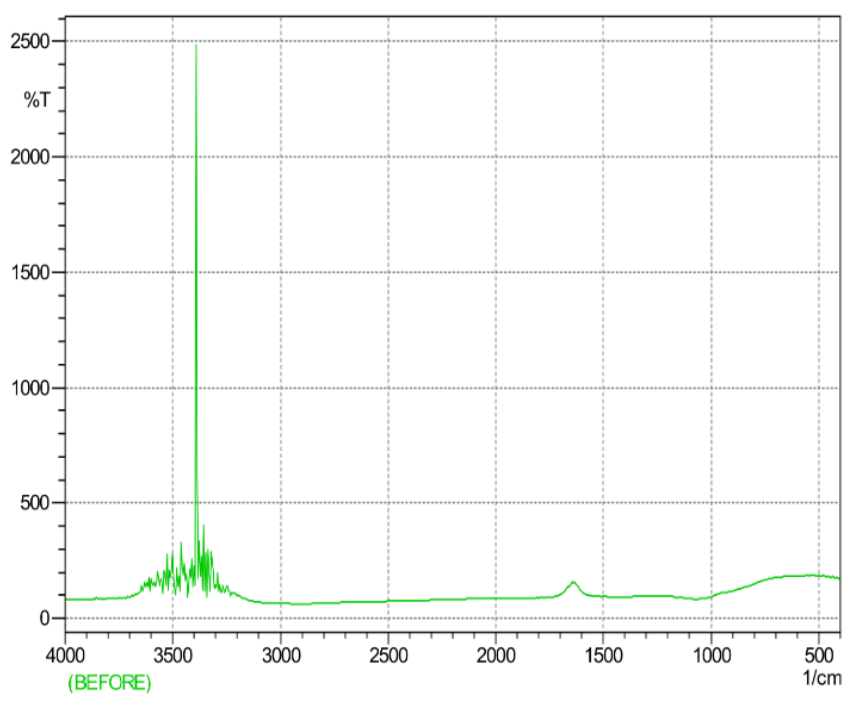

Fig-1. FTIR plot before activation

\section{FTIR spectrum of untreated powder}

FTIR spectrum of untreated Hen Feathers powder is depicted in Fig.I the peak is found at $1157 \mathrm{~cm}^{-1}$ denotes the involvement and participation of $=\mathrm{CH}$ bend alkenes mode in adsorption. The band at $3230 \mathrm{~cm}^{-1}$ and $3273 \mathrm{~cm}^{-1}$ indicates Hydroxyl, Alcohol and Phenol classification. The peak near 3591 /cm and 3622 /cm indicates O-H (Alcohol) group

\section{FTIR spectrum of treated powder}

FTIR measurements for MG dye loaded with Hen Feathers are shown in Fig. II the peaks at $680 \mathrm{~cm}^{-1}$ indicates Alkyl halides (C-Cl). The peak at $1465 \mathrm{~cm}^{-1}$ shows Alkyl $\mathrm{C}-\mathrm{H}$ stretch mode. The peak at $3217 \mathrm{~cm}^{-1}$ shows non-symmetric $\mathrm{CH}_{2}$, Symmetric $\mathrm{CH}_{3} \& \mathrm{CH}_{2}$ stretching vibrations. The peak at $3286 \mathrm{~cm}^{-1}$ shows Amine NH group. The bands at $3759 \mathrm{~cm}^{-1}, 3801 \mathrm{~cm}^{-1}$ and $3817 \mathrm{~cm}^{-1}$ indicate non bonded O-H stretch Hydroxyl group. The peak at 3992 $\mathrm{cm}^{-1}$ indicates $\mathrm{O}-\mathrm{H}$ group as well as Amine $\mathrm{N}-\mathrm{H}$ stretch modes.

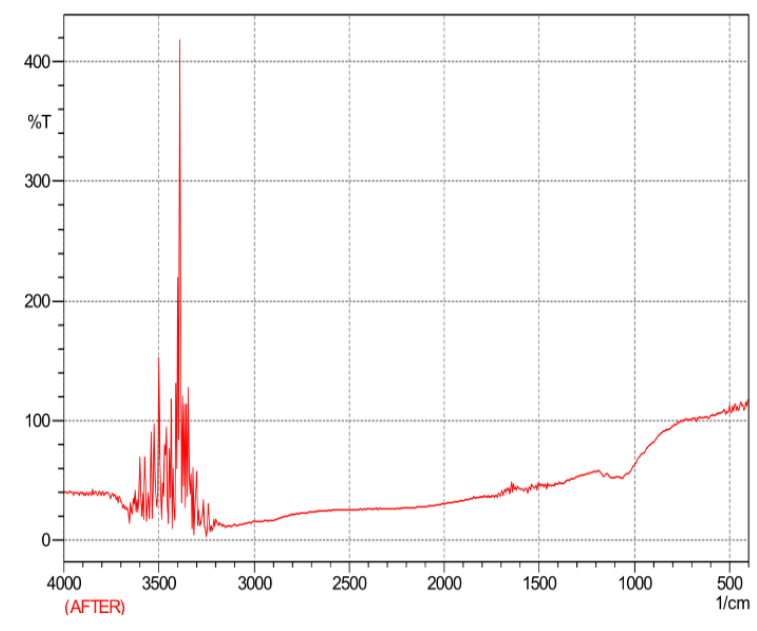

Fig.II. FTIR plot after activation

\section{B. Adsorption Study of the Fixed Bed Column on BTC}

The majority of sorption-based separation and purification processes use the continuous flow columns. The packed bed column is a better process equipment for regular treatment of waste water in biosorption applications, as it makes the complete use of the concentration diff known to be a drive for biosorption, allowing for more effective utilisation of biosorption capacity and better effluent quality. In this experiment, a fixed bed is used to collect biosorption data. In batch biosorption studies, activated hen feathers powder showed greater MG absorption. Activated hen feathers powder is used to create the permanent bed. To examine MG biosorption as a function of aqueous solution flow rate, starting MG concentration, and bio sorbent bed height, a continuous flow packed bed column was used. Breakthrough curves are utilized to evaluate the record of observation of a packed bed column. The next sections cover the experimental results as well as the application of various models.

\section{Effects of adsorbate Flow rate}

Flow rate has a major impact on the record of observation of the column in a continuous mode research, and it's typically a critical parameter for measuring adsorbent efficiency during the continuous adsorption of effluents on a pilot or in large scale. To determine the influence of flowrate on the performance of activated Hen feathers powder bed, columns are run at varied flow rates of $4,8, \& 12$ milli litre/min with a fixed bed depth of $8 \mathrm{~cm}$ and an initial concentration of $20 \mathrm{ppm}$. The $\mathrm{pH}$ of the aqueous solution is initially kept at 4 .. The breakthrough curves for flow rates of 4,8 , and $12 \mathrm{ml} / \mathrm{min}$ are shown in Figure III. C2/C1=0.1 and $\mathrm{C} 2 / \mathrm{C} 1=0.9$ are the breakthrough and exhaust times, respectively. The flowrate was adjusted to obtain the highest elimination of MG dye, and it was discovered that a flow rate of 4 milli litre/min achieved the most absorption. At this flow rate (4-12 $\mathrm{ml} / \mathrm{min})$, the percentage removal of MG dye was around 56.603-51.067 percent, and the removal percent dropped as the flow rate increased. With a constant maintenance of bed's height at $8 \mathrm{~cm}$ and a malachite green conc of 20mg/l intake, flow rates of $\mathrm{ml} / \mathrm{min} 4,8 \mathrm{ml} / \mathrm{min}$, and $12 \mathrm{ml} / \mathrm{min}$ were tested. Break through times are 165,120 , and 105 minutes, respectively and the exhaust times are 450, 330, and 270 minutes. The time it takes to reach break through has decreased as the flow rate has increased. Similarly, with reduced flow rate contact with biosorbent, exhaustion times increased, indicating a greater removal of MG, inadequate solute residence time in the column, and less solute diffusion into the pores of the biosorbent, indicating that the solute leaving the column before reaching the equilibrium. Maximum absorption capacities were determined to be 1.67 , 2.21 , and $2.829 \mathrm{mg} / \mathrm{g}$ at flow rates of $4 \mathrm{ml} / \mathrm{min}, 8 \mathrm{ml} / \mathrm{min}$, and $12 \mathrm{ml} / \mathrm{min}$. The BTCs revealed that adsorption was initially extremely quick at all three flow rates $(4,8$ and $12 \mathrm{ml} / \mathrm{min})$, which might be due to a plentiful number of reaction sites ready to trap dye molecules surrounding or within the cells. Because those locations were gradually occupied, the uptake came to be very less effective in the following step. The column has capacity of collecting MG even after the breakthrough occurred, albeit at a decreased efficiency. The BTC became steeper when the flow is increased, leading in a decrease in the break point time \& adsorbed concentration of MG. When the MG adsorbate's residence time in the column seemed not sufficient to achieve adsorption equilibrium @ particular flow rate, the beginnig of the adsorption zone soon reached the zenith of the column and it saturated the column prematurely, and the MG solution exited the column before getting equilibrium was established. [26].

Blue Eyes Intelligence Engineering and Sciences Publication

(C) Copyright: All rights reserved.

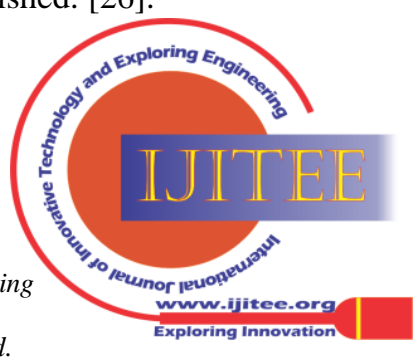


As the contact period of MG dyes with Hen Feathers is relatively brief at the higher flow rate, a decrease in removal efficiency occurs. With a low influent rate, MG took more time to touch the activated Hen feather powder giving a not so deep adsorption zone and increased MG dye molecule removal in the column. As can be observed from Table II, the dye removal \% of the column decreases as the flow increases. Table 2 shows that at flow rates of 4 and $12 \mathrm{~mL} / \mathrm{min}$, the breakthrough time decreases from 165 to 105 minutes. The contrast between the slopes of BTC and adsorption capacity can be determined using mass-transfer principles. The speed of mass transfer rises with greater flow, i.e., the quantity of dye biosorbed on the given MTZ raised with higher flow, resulting in quick saturation at a high flow rate [27]. The findings of MTZ or underused beds (HUNB) given in Table I backed up this notion.

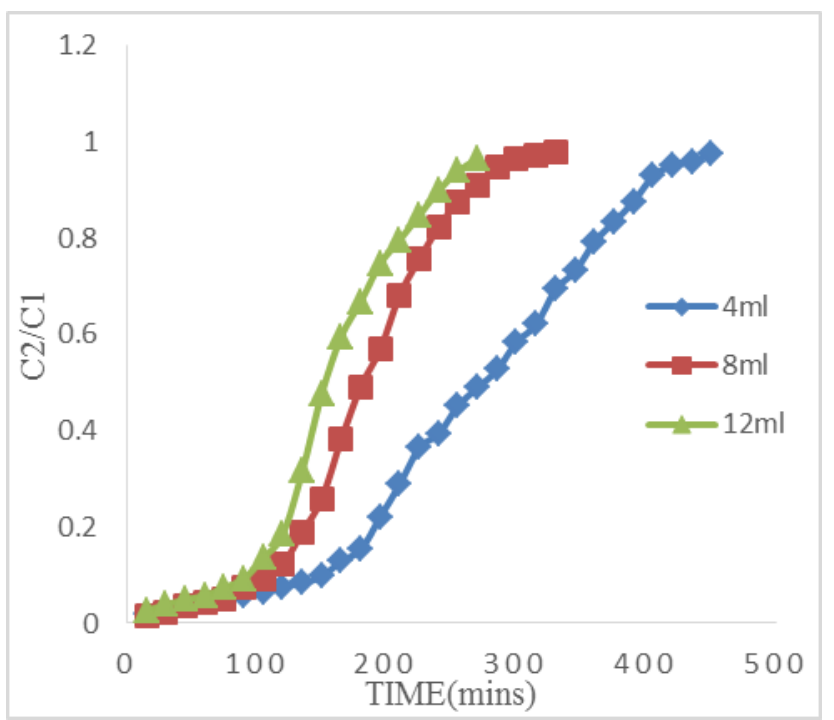

Fig.III. Plot for varying flow rate of Adsorption of Malachite Green using Hen Feathers

\section{Effect of the inlet concentration of adsorbate}

The influence of inlet dye concentration in the input flow is one of the limiting parameters, as well as one of the key process variables. Because a particular mass of adsorbent can adsorb only a certain quantity of dye, the effluent's initial dye concentration is critical. As a result, the amount of effluent that a hard and fast mass of adsorbent can filter decreases as an effluent becomes more concentrated. The MG dye concentration was changed between 10 and $30 \mathrm{mg} / \mathrm{l}$ in the column tests to examine the influence of concentration of the adsorbate on the act of BTC. While the experiment, other conditions like bed's height of $8 \mathrm{~cm}$ as well as flow rate of 8 $\mathrm{ml} / \mathrm{min}$ are made constant. The biosorption BTCs for the adsorbate conc. of $10 \mathrm{mg} / \mathrm{L}, 20 \mathrm{mg} / \mathrm{L}$, and $30 \mathrm{mg} / \mathrm{L}$ are shown in Fig.IV. As shown in Figure, for low MG dye inlet concentrations, the top of the adsorbent is completely filled with MG after some time, and the breakthrough was also delayed, but for higher MG concentrations, the breakthrough was achieved in a shorter time. The breakthrough was flatter at lower intake MG concentrations, indicating a reasonably broad MTZ and a film-controlled process. The BTCs, on the other hand, were sharpened at higher intial MG concentrations, indicating a lesser MTZ and a diffusion-controlled intra-particle mechanism. The findings were found to be consistent with those of other studies [28-30]. Figure IV demonstrates that when the influent MG concentration increased, the breakthrough time decreased.
These findings inform that the breakthrough time as well as saturation rate are affected by changes in concentration gradient [31]. Much More Biosorption sites are covered as the MG concentration increased, according to one theory. The steep, the slope of BTC and the shorter the breakthrough period, the higher the influent concentration. Reduced inlet MG dye concentrations resulted in delayed BTCs, as well as a larger treated volume, because the smaller concentration gradient resulted in slower movement due to a lower diffusion coefficient [32,33]. At the maximum MG concentration ( $30 \mathrm{mg} / \mathrm{l})$, the binding sites of the hen feathers became steep faster, resulting in an early moment of breakthrough and exhaust time, as shown in Table II. Different parameters of BTCs of packed bed column for the separation of MG by hen feathers at various MG concentrations were shown in this table, and it indicates that the quantity of total dye removed, equilibrium dye uptake, and Mass Transfer Zone increase with increasing inlet MG dye concentration, whereas the total percentage of removal decreases. When the initial MG dye concentration was raised from 10 to $30 \mathrm{mg} / \mathrm{L}$, the total quantity of MG dye adsorbed rose from 17.2649 to $28.3985 \mathrm{mg}$, but the percentage MG removal fell from 53.287 to 49.3 percent (Table I). The adsorbent's absorption capacity increases as the incoming MG concentration rises, giving more driving power for the rate of transfer process to rise above mass transfer confrontation. Similarly, at low conc, the dye mols in the solution engage with the adsorbent's binding sites, allowing for greater adsorption. All adsorbents, on the other hand, have a finite no. of binding sites that become saturated at a particular conc [34]. As a result of the saturation of binding sites, more and more dye mols are left unadsorbed in the sol at higher conc, resulting in decreased adsorption efficiency.

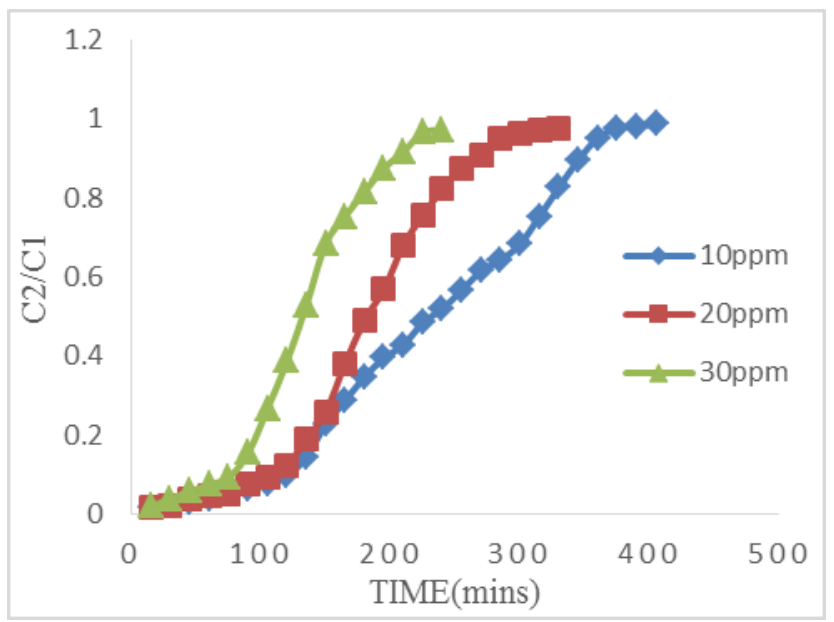

Fig. IV. BTC for biosorption of MG dye onto activated hen feather powder at several initial MG conc

\section{Effect of height of bed of the adsorbent}

One of the most significant elements in the observation of a biosorption system, especially in a continuous column process, is bed height. The tests used 9.147, 12.196, and $15.245 \mathrm{~g}$ of bio sorbent for three distinct bed heights of 6,8 , and $10 \mathrm{~cm}$.

Published By:

Blue Eyes Intelligence Engineering and Sciences Publication

(C) Copyright: All rights reserved. 


\section{Biosorption of Malachite Green Dye from Wastewater with Henfeathers -Analysis of Various Mathematical Models Wrt Continuous Adsorption}

Because the amount of adsorbents inside a fixed-bed column determines how much adsorbate accumulates, the steep nature of all BTCs can be a relation of bed's height.. To determine the impact of bed height on the BTC, an inlet MG concentration of 20 milligram/liter, $\mathrm{pH} 4$, and flow rate of 8 milliliter/min via column by changing the bed's height. The observation of BTCs at varied column depths of 6,8 , and 10 $\mathrm{cm}$ is shown in Figure V. The breakthrough time varies with bed height, as depicted in Fig.V. The time of break through rose from 75 minutes to 135 minutes while the bed's height is increased from 6 to $10 \mathrm{~cm}$. The capacity of the bed and the effectiveness of biosorption were both shown to improve as the bed height was raised. The residence duration of the MG in the column raised as the bed height rose, making the dye molecules to penetrate deep into the activated hen feather powder, which gives in better dye removal efficiency. $[35,36]$. Because of increment in the surface-area of hen feathers, due to which in many binding areas for the binding of MG dye molecules for the adsorption process, higher absorption was reported at the top value of bed's height [37]. When the bed height was increased, the amount of effluent which was treated, time of break through,as well as time of exhaustion all improved. (See Table III) Because the breakthrough time is a process parameter, the more the time of break through, the good the inner particulate phenomena and the greater the column's Biosorption capacity [38]. This may be explained by the fact which is when the bed's height was increased, the axial dispersion in the mass transfer rate showed a decrease, and as a result, the dye molecules' diffusion into the biosorbent improved. As a result, the solute had ample time to diffuse throughout the adsorbent, allowing it to stay in the column for longer and treat a larger vol. of effluents. [39].

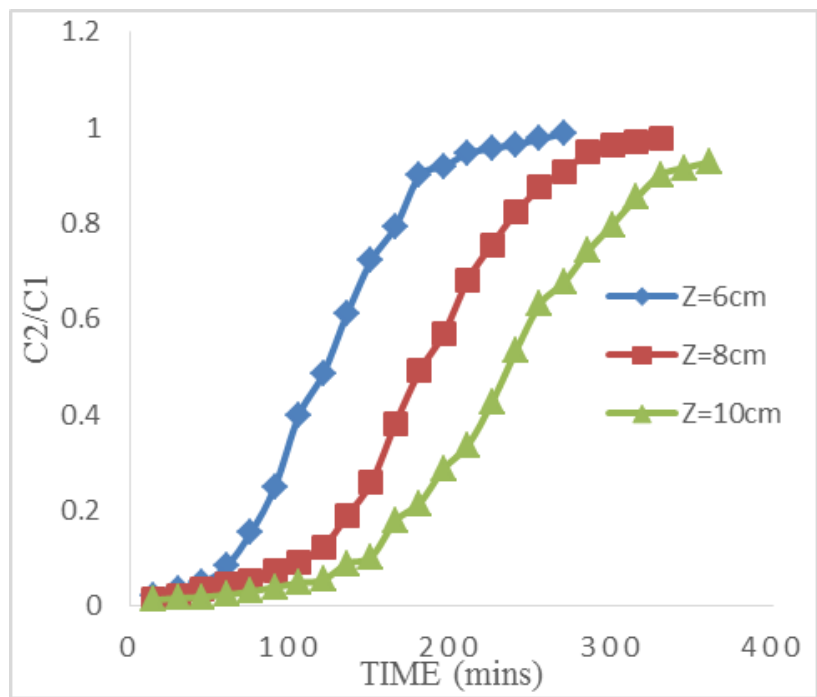

Fig.V. BTC for biosorption of MG dye onto activated hen feather powder at several bed heights

\section{Application of Different BTC Models}

Prediction of the concentration time profile is very much essential for effective setup of a column biosorption process. The fixed bed biosorption has been described using a variety of mathematical models. Many studies have been published that use the Bohart-Adams model to assess the kinetics of biosorption in the column. Thomas, BDST, \& Yoon-basic nelson were the other models that were evaluated for packed bed column biosorption data. The aim of this work is to identify the optimum model for explaining biosorption kinetics in a column.

\section{Application: Bohart-Adams model:}

The Bohart-Adams model was used to describe the first portion of the break through curve using experimental data. The model's mathematical equation may be expressed as:

$$
\ln \frac{C_{2}}{C_{1}}=k_{A B} C_{1} t-k_{A B} N_{0} \frac{z}{V_{0}}
$$

Table-II: Fixed bed parameter studies

\begin{tabular}{|c|c|c|c|c|c|c|c|c|}
\hline $\begin{array}{c}\text { Flo } \\
\text { w } \\
\text { rat } \\
\text { e, } \\
\text { ml/ } \\
\text { mi } \\
\text { n }\end{array}$ & $\begin{array}{c}\text { Ti } \\
\text { me, } \\
\text { mi } \\
\text { n }\end{array}$ & $\begin{array}{c}\text { Vol } \\
\text { um } \\
\text { e of } \\
\text { effl } \\
\text { uen } \\
\text { t, } \\
\text { ml }\end{array}$ & $\begin{array}{l}m_{t c} \\
\mathrm{mg}\end{array}$ & $\boldsymbol{q}_{\text {toto }}$ & & $\begin{array}{l}\% \\
Y\end{array}$ & $\begin{array}{c}\mathbf{M} \\
\mathbf{T Z}\end{array}$ & $\mathrm{H}_{B}$ \\
\hline $\begin{array}{c}4 \\
8 \\
12\end{array}$ & $\begin{array}{l}450 \\
330 \\
270\end{array}$ & $\begin{array}{l}1.8 \\
15 \\
2.6 \\
60 \\
3.2 \\
58\end{array}$ & $\begin{array}{c}36 \\
52 . \\
8 \\
64 . \\
8\end{array}$ & $\begin{array}{c}20 . \\
377 \\
2 \\
26 . \\
963 \\
4 \\
34 . \\
508 \\
\end{array}$ & $\begin{array}{c}1.6 \\
7 \\
2.2 \\
1 \\
2.8 \\
29\end{array}$ & $\begin{array}{c}56 . \\
603 \\
51 . \\
067 \\
53 . \\
25\end{array}$ & $\begin{array}{c}3.1 \\
7 \\
2.6 \\
94 \\
2.6 \\
208\end{array}$ & $\begin{array}{c}4.8 \\
29 \\
5.3 \\
06 \\
5.3 \\
796\end{array}$ \\
\hline \multicolumn{9}{|c|}{ Initial concentration, mg/l } \\
\hline $\begin{array}{c}10 \\
\mathrm{mg} / \\
\mathrm{l} \\
30 \\
\mathrm{mg} / \\
\mathrm{l}\end{array}$ & $\begin{array}{l}405 \\
240\end{array}$ & $\begin{array}{l}3.2 \\
64 \\
1.9 \\
33\end{array}$ & $\begin{array}{c}32 . \\
4 \\
57 . \\
6\end{array}$ & $\begin{array}{c}17 . \\
264 \\
9 \\
28 . \\
398 \\
5\end{array}$ & $\begin{array}{l}1.4 \\
15 \\
2.3 \\
28\end{array}$ & $\begin{array}{c}53 . \\
25 \\
49 . \\
3\end{array}$ & $\begin{array}{c}3.3 \\
552 \\
2.4 \\
848\end{array}$ & $\begin{array}{r}4.6 \\
448 \\
5.5 \\
152\end{array}$ \\
\hline \multicolumn{9}{|c|}{ Bed height, cm } \\
\hline $\begin{array}{c}6 \mathrm{c} \\
\mathrm{m} \\
10 \mathrm{c} \\
\mathrm{m}\end{array}$ & $\begin{array}{l}270 \\
360\end{array}$ & $\begin{array}{c}2.1 \\
76 \\
2.8 \\
92\end{array}$ & $\begin{array}{c}43 . \\
2 \\
57 . \\
6\end{array}$ & $\begin{array}{c}17 . \\
403 \\
1 \\
35 . \\
046 \\
7\end{array}$ & $\begin{array}{c}1.9 \\
02 \\
2.2 \\
988\end{array}$ & $\begin{array}{c}40 . \\
285 \\
60 . \\
845\end{array}$ & $\begin{array}{c}2.2 \\
392 \\
3.5 \\
1\end{array}$ & $\begin{array}{c}3.7 \\
608 \\
6.4 \\
9\end{array}$ \\
\hline
\end{tabular}

Where $C_{1}$ and $C_{2}$ are input \& output adsorbate concentrations respectively in mgL-1, $\mathrm{z}$ is the bed's height in centi $\mathrm{m}, V_{0}$ is the superficial velocity in $\mathrm{cm} / \mathrm{min}, \mathrm{N}$ is the saturation concentration in ppm and $K_{A B}$ is the kinetic constant in $\mathrm{L} / \mathrm{mg}$ min

The characteristic parameters like saturation concentration $\left(N_{0}\right)$ and kinetic constant $\left(K_{A B}\right)$ were to be assumed in this approach. In the current study, the interval of time considered is shown in the table. Time considered for calculation of model conditions.

Values of $\ln \left(C_{2} / C_{1}\right)$ are depicted against t at various flow rates, inlet MG concentration \& bed's heights are shown in Fig below. The kinetic constant $\left(K_{A B}\right)$ as well as saturation conc. $\left(N_{0}\right)$ were computed using the slope(m) and intercept (c) of curves which are given in table.

Published By:

Blue Eyes Intelligence Engineering and Sciences Publication

(C) Copyright: All rights reserved.

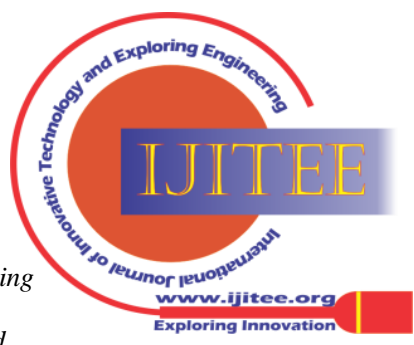


The kinetic constant increased with the increment in flow velocity, decreasing starting conc \& increasing bed's height, as shown in Table III. This indicates that in the early stages of biosorption in the column, exterior mass transfer subjugated the kinetics of the system. The Bohart-Adams model is restricted in the range of circumstances employed, despite the fact that it provides a straightforward and comprehensive strategy for performing and assessing sorption-column tests.

Table-III: Bohart-Adams model parameters

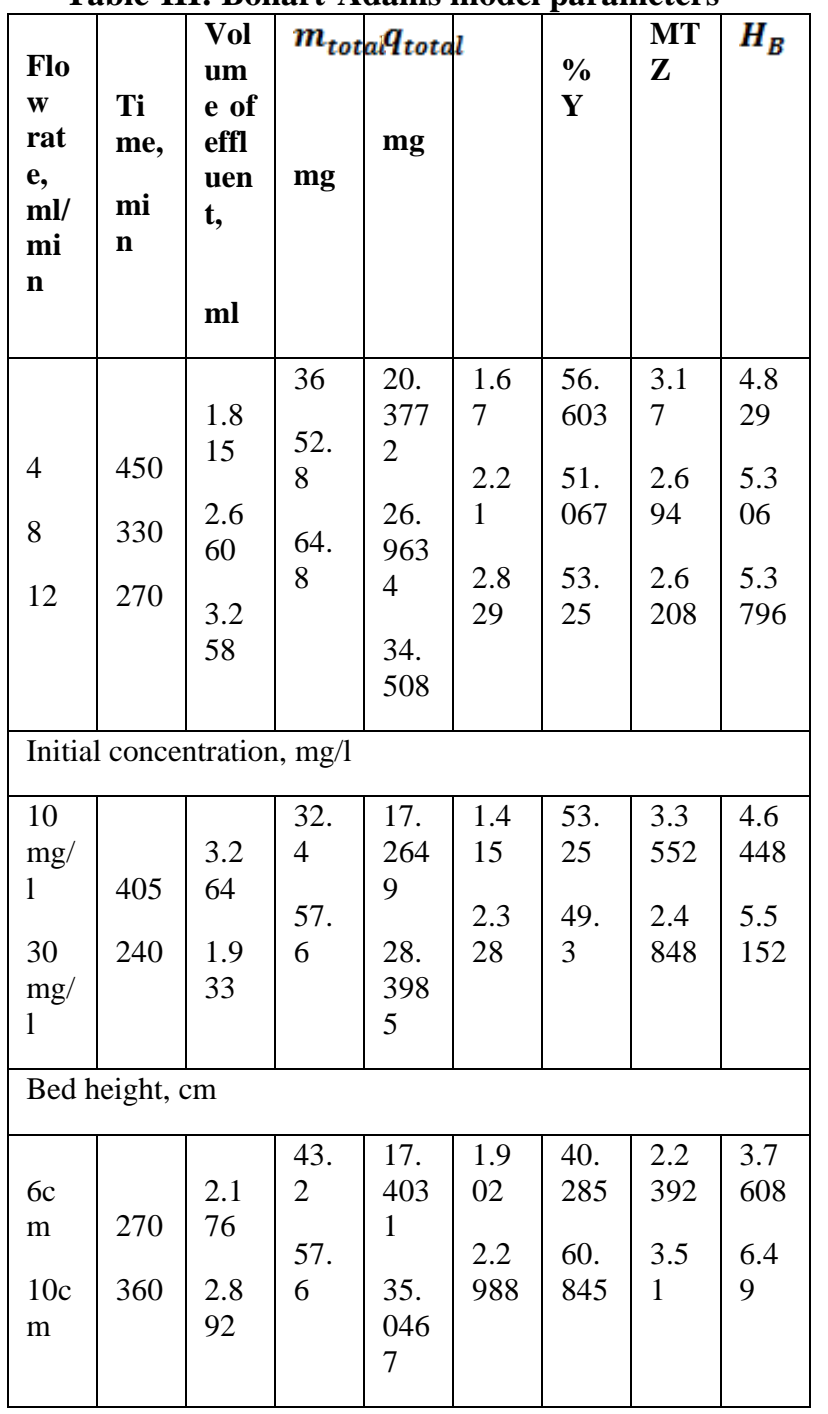

\section{Application of BDST Model.}

The BDST curve was developed using experimental data from Colin studies. The BDST model is written as follows: $=\frac{N_{0} z}{C_{1} u}-\frac{1}{k C_{1}} \ln \left(\frac{C_{1}}{C_{2}}-1\right)$

Where $C_{1}$ and $C_{2}$ are the inlet \& outlet conc respectively, wherein $\mathrm{k}$ is adsorption rate constant $(\mathrm{l} / \mathrm{mg} \mathrm{min})$, No is termed as adsorption capacity $(\mathrm{mg} / \mathrm{L}) \mathrm{z}$ is bed's depth $(\mathrm{cm})$ and $\mathrm{t}$ is service time for breakthrough (min).

$\mathrm{K}$ and No values are computed from the slope \& intercept of the graph between $\ln \left(C_{1} / C_{2}-1\right)$ verses time $t$ at various biosorption conditions such as the flow rate, the input biosorbate's concentration and the bed's height were shown. The expected results of characteristic quantities like $\mathrm{k}$ and $N_{0}$ are presented in Table IV.
Table-IV: BDST parameters

\begin{tabular}{|l|l|l|l|}
\hline \multicolumn{4}{|c|}{ Flow rate, $\mathrm{ml} / \mathrm{min}$ variable, $\mathrm{z}=8 \mathrm{~cm}, C_{1}=20 \mathrm{mg} / \mathrm{l}$} \\
\hline $\mathrm{Q}, \mathrm{ml} / \mathrm{min}$ & $\mathrm{Kab}{ }^{*} 10^{\wedge}-4$ & $\mathrm{No}, \mathrm{mg} / \mathrm{l}$ & $\mathrm{R} 2$ \\
\hline $4 \mathrm{ml}$ & 8.35 & 375.4981 & 0.9855 \\
\hline $8 \mathrm{ml}$ & 13.14 & 514.8478 & 0.9954 \\
\hline $12 \mathrm{ml}$ & 13.95 & 673.6306 & 0.9886 \\
\hline
\end{tabular}

Initial malachite green concentration, $\mathrm{mg} / \mathrm{l}$ variable, $\mathrm{Q}=8 \mathrm{ml} / \mathrm{min}, \mathrm{z}=8 \mathrm{~cm}$

\begin{tabular}{|l|l|l|l|}
\hline $10 \mathrm{mg} / \mathrm{l}$ & 20.59 & 317.6645 & 0.9723 \\
\hline $30 \mathrm{mg} / \mathrm{l}$ & 11.23 & 566.0297 & 0.9949 \\
\hline Bed height, cm variable, Q=8ml/min, $C_{1}=20 \mathrm{mg} / \mathrm{l}$ \\
\hline $6 \mathrm{~cm}$ & 16.48 & 480.6794 & 0.9904 \\
\hline $10 \mathrm{~cm}$ & 10.68 & 534.6242 & 0.9939 \\
\hline
\end{tabular}

\section{Application: Yoon-basic Nelson model}

Yoon-basic Nelson's theoretical model was put to the test in order to explore the breakthrough behaviour of MG on Hen feathers powder. The linearsied model for a single component system is stated as:

$$
\ln \left(\frac{c_{2}}{c_{1}-C_{2}}\right)=k_{Y N} t-\tau k_{Y N}
$$

Where $k_{Y N}$ the rate constant $(1 / \mathrm{min})$, $\mathrm{t}$ is is termed as the time required to get 50 percent adsorbate breakthrough (min).

The values of $k_{Y N}$ and $t$ were computed from the plots drawn between $\ln \left(\frac{C_{2}}{C_{1}-C_{2}}\right)$ verses time $t$ at several flow rates, input concentration and bed's height are shown in figs. The values rose as the flow velocity and starting MG concentration increased, but the $t$ trended in the other direction. Increases in bed height resulted in decreases in and a reversal of the trend on $t$. Table 1 shows the anticipated uptake values from the model, as well as experimental uptake values, as well as values for and $t$ and statistical parameters. Table V shows that theoretical uptake capacity is extremely similar to those anticipated by the Yoon-Nelson model in the majority of situations.

Table-V: Yoon-Nelson model parameters

\begin{tabular}{|l|l|c|l|}
\hline \multicolumn{4}{|c|}{ Flow rate, $\mathbf{~ m l} / \mathbf{m i n}$ variable, $\mathbf{z}=\mathbf{8 c m}, \boldsymbol{C}_{\mathbf{1}}=\mathbf{2 0} \mathbf{~ m g} / \mathbf{l}$} \\
\hline $\mathrm{Q}, \mathrm{ml} / \mathrm{min}$ & $k_{Y N}$ & $\mathrm{t}$ & $R^{2}$ \\
\hline $4 \mathrm{ml}$ & 0.0165 & 265.1152 & 0.9855 \\
\hline $8 \mathrm{ml}$ & 0.0262 & 181.6985 & 0.9954 \\
\hline $12 \mathrm{ml}$ & 0.0276 & 158.6667 & 0.9886 \\
\hline
\end{tabular}

Initial malachite green concentration, $\mathrm{mg} / \mathrm{l}$ variable, $\mathrm{Q}=\mathbf{8 m \mathrm { ml }} / \mathbf{m i n}, \mathrm{z}=\mathbf{8 c m}$

\begin{tabular}{|l|l|l|l|}
\hline $10 \mathrm{mg} / \mathrm{l}$ & 0.02 & 225.07 & 0.9723 \\
\hline $30 \mathrm{mg} / \mathrm{l}$ & 0.0335 & 133.4179 & 0.9949 \\
\hline Bed height, cm variable, $\mathrm{Q}=8 \mathrm{ml} / \mathrm{min}, C_{1}=20 \mathrm{mg} / \mathrm{l}$ \\
\hline $6 \mathrm{~cm}$ & 0.0326 & 127.3436 & 0.9904 \\
\hline $10 \mathrm{~cm}$ & 0.0212 & 236.6368 & 0.9939 \\
\hline
\end{tabular}

\section{CONCLUSIONS}

The main motive of this study is to establish the suitability of Activated Hen feathers as bisorbents for the continuous elimiation of malachite Green from waste water. Studies on fixed beds. The following findings are made from this research.

Published By:

Blue Eyes Intelligence Engineering and Sciences Publication

(C) Copyright: All rights reserved. 


\section{Biosorption of Malachite Green Dye from Wastewater with Henfeathers -Analysis of Various Mathematical Models Wrt Continuous Adsorption}

- With a increase in flow starting from $4 \mathrm{ml} / \mathrm{min}$ to 12 $\mathrm{ml} / \mathrm{min}$, the time of breakthrough (165 to 105 minutes) and the time of exhaust (450 to 270 minutes) have decreased. • With an increment in initial malachite green concentration from 10 to $30 \mathrm{mg} / \mathrm{l}$, the time of breakthrough (135 to 90 minutes) and the time of exhaust (405 to 240 minutes) have decreased.

-while the bed height is improved from 6 to $10 \mathrm{~cm}$, the breakthrough time (75 to 135 minutes) and exhaust duration (270 to 360 minutes) rose as well.

- To forecast breakthrough curves and identify the features of column parameters, Bohart-adams, BDST model, Thomas, and Yoon-basic Nelson are used.

- Significant and distinguishing aspects of the various models, such as service duration (Hutchins BDST model), biosorption capacity (bohart-adams model), and 50 percent breakthrough (Yoon-Nelson model), were identified.

The kinetics of malachite green biosorption in column were best characterised by the BDST and Yoon-Nelson models based on the exact parameters.

\section{REFERENCES}

1. Uma, S. Banerjee, and Y.C. Sharma. "Equilibrium and kinetic studies for elimination of malachite green from waste water by a low cost activated carbon”, J. Ind. Eng. Chem.,2013,vol.19,pp.1099-1105.

2. D. Podstawczyk, A. Witek-Krowiak, K. Chojnacka, and Z. Sadowski. "Biosorption of malachite green by egg shells: Mechanism identification and process optimization", Bioresour.Technol.,2014,pp.161-165.

3. A. Witek-Krowiak. "Biosorption of malachite green from aqueous solutions by pine sawdust: Equilibrium, kinetics and the effect of process parameters", Desalin. Water Treat.,2013, vol. 51, pp.3284-3294.

4. S. Srivastava, R. Sinha, and D. Roy. "Toxicological effects of malachite green”, Aquat. Toxicol., 2004,vol. 66, pp. 319-329.

5. S.J. Culp, and F.A Beland. "Malachite green: a toxicological review", J. Am. Coll. Toxicol., 1996, vol. 15, pp. 219-238.

6. S. Srivastava, R. Sinha, and D. Roy. "Toxicological effects of malachite green”, Aquat. Toxicol., 2004, vol. 66, pp.319- 329.

7. S.M. Donya, A.A. Farghaly, M.A. Abo-Zeid, H.F. Aly, S.A. Ali, M.A. Hamed, and N.S. El Rigal. "Malachite green induces genotoxic effect and biochemical disturbances in mice", Eur. Rev. Med. Pharmacol. Sci., 2012, vol. 16, pp. 469-482.

8. R. Gong, Y. Ding, M, Li, C. Yang, H. Liu, and Y. Sun. "Utilisation of powdered peanut hull as biosorbent for removal of anionic dyes from aqueous solution", Dyes Pigment.,2005, vol. 3, pp. 187-192. doi:10.1016/j.dyepig.2004.05.005

9. M.A.M. Salleh, D.K Mahmoud, W.A.W. Karim, and A. Idris. "Cationic and anionic dye adsorption by agricultural solid wastes: a comprehensive review", Desalin., 2011, vol. 280, pp. 1-13. doi:10.1016/j.desal.2011.07.019.

10. Z. Zhang, I.M. O'Hara, G.A. Kent, and W. Doherty. "Comparative study on adsorption of two cationic dyes by millet sugarcane bagasse", Ind Crop Prod., 2013, vol.42, pp. 41-49. doi:10.1016/j.indcrop.2012.05.008.

11. S. Al-Asheh, F. Banat, and D. Al-Rousan. "Adsorption of copper, zinc and nickel ions from single and binary metal ion mixtures on to chicken feathers", Adsorp. Sci. Technol., 2002, vol. 20, pp. 849-864.

12. F. Banat, S. Al-Asheh, and D. Al-Rousan. "Comparison between different keratin-composed biosorbents for the removal of heavy metal ions from aqueous solutions", Adsorp. Sci. Technol., 2002, vol. 20, pp. 393-416.

13. S. Al-Asheh, F. Banat, and D. Al-Rousan. "Beneficial reuse of chicken feathers in removal of heavy metals from wastewater", J. Cleaner Prod., 2003, vol. 11, pp. 321-326.

14. D.I. Ishikawa, and K. Suyama. "Recovery and refining of au by gold-cyanide ion biosorption using animal fibrous proteins", Appl. Biochem. Biotechnol. Part A: Enzyme Eng. Biotechnol., 1998, pp. 719-728.

15. M.T. Yagub, T.K. Sen, S. Afroze, and H.M. Ang. "Dye and its removal from aqueous solution by adsorption: A review", Desalin. Water Treat., 2014, vol. 209, pp. 172-184.
16. S. Ghorai, and K. Pant. "Equilibrium, kinetics and breakthrough studies for adsorption of fluoride on activated alumina", Sep. Purif. Technol., 2005,pp. 265

17. M.L. Bao, O. Griffini, D. Santianni, K. Barbieri, D. Burrini, and F. Pantani. "Water quality factors affecting Bromatereduction in Biologically active carbon filters". Water Res.,1999,vol.33,pp.2959.

18. S.D. Faust, and O.M. Aly. "Adsorption Processes for Water Treatment", Acta hydrochim. Hydrobiol., 2013.

19. M.T. Yagub, T.K. Sen, S. Afroze, and H.M. Ang." Dye and its removal from aqueous solution by adsorption: a review", Adv. Colloid Interface Sci., 2014, vol. 209, pp.172-184.

20. G. Walker, L. Weatherley. "Adsorption of Methylene Blue onto activated carbon produced from steam activated bituminous coal: A study of equilibrium adsorption isotherm", Sci. Technol., 2000,vol.35,pp.1329.

21. Y. Al-Degs, M. Khraisheh, and M. Tutunji." Sorption of lead ions on diatomite and manganese oxides modified diatomite", Water Res., 2001, vol. 35,pp. 3724-3728.

22. G. Bohart, and E. Adams. "Some aspects of the behavior of charcoal with respect to chlorine", J Am Chem Soc., 1920, vol. 42, pp. 523-544.

23. E. Guibal, R. Lorenzelli, T. Vincent, and P.L. Cloirec. "Application of silica gel to metal ion sorption: static and dynamic removal of uranyl ions, Environ Technol., 1995, vol. 16, pp. 101-111.

24. M.L.G. Vieira, V.M. Esquerdo, L.R. Nobre, G.L. Dotto, and L.A.A. Pinto, "Glass beads coated with chitosan for the food azo dyes adsorption in a fixed bed column", J. Ind. Eng. Chem. 2014, vol. 20, pp. 3387-3393.

25. Z. Xu, J.G. Cai, and B.C. Pan. "Mathematically modeling fixed-bed adsorption in aqueous systems", J Zhejiang Univ Sci A., 2013, vol. 14(3), pp. 155-176.

26. S. Ghorai, and K. Pant. "Equilibrium, kinetics and breakthrough studies for adsorption of fluoride on activated alumina", Sep. Purif Technol., 2005 vol. 42, pp. 265.

27. D.C. Ko, J.F. Porter, and G. McKay. "Optimized Correlation for the Fixed Bed Adsorption of Metal Ions on Bone Char", Chem. Eng. Sci., 2000, vol. 55, pp. 5819-29.

28. M.S. Reddy, and V. Nirmala. "Bengal gram seed husk as an adsorbent for the removal of dyes from aqueous solutions - Column studies". Arab. J. Chem.,, 2014.

29. K.S. Bharathi, and S.P.T. Ramesh. "Fixed bed adsorption of fluoride by Artocarpus hirsutus based adsorbent", Appl. Water Sci.., 2013, vol. 3, pp. 673.

30. M. Hadi, M.R. Samarghandi, and G. McKay. "Simplified fixed bed design models for the adsorption of acid dyes on novel pine cone derived activated carbon", Water Air Soil Pollut., 2011, vol. 218, pp. 197.

31. J. Goel, K. Kadirvelu, C. Rajagopal, and V.K. Garg. "Preparation of agricultural by-product based anion exchanger and its utilization for nitrate and phosphate removal", J. Hazard. Mater., 2005, vol.125, pp.211.

32. R. Han, Y. Wang, W. Yu, and W. Zou. J. Shi, and H. Liu. "Packed-Bed Column Adsorption of Metanil Yellow (MY) from Simulated Wastewater using Granular $\mathrm{NaOH}$-Activated Carbon from Cassava (Manihot esculenta) Peels", J. Hazard. Mater., 2007, vol. 141, pp. 713.

33. T. Padmesh, K. Vijayaraghavan, G. Sekaran, and M. Velan. "Batch and column studies on biosorption of acid dyes on fresh water macro alga Azolla filiculoides", J. Hazard. Mater., 2005, vol. 125,pp. 121-29.

34. S. Chowdhury, R. Mishra, P. Saha, and P. Kushwaha. "Adsorptive Accumulation of Methylene Blue Dye from Aqueous Effluent by NiFe 2 O 4-GO Nano-adsorbent", Desalination., 2011, vol. 265,pp. 159-168.

35. I.Mobasherpour, E. Salahi, and A. Asjodi. "Comparative of the removal of $\mathrm{Pb} 2+, \mathrm{Cd} 2+$ and $\mathrm{Ni} 2+$ by nano crystallite hydroxyapatite from aqueous solutions: adsorption isotherm study," Soil Water., 2014, vol. 4,pp. 5.

36. P.D. Saha, S. Chowdhury, M. Mondal, and K. Sinha. "Biosorption of Direct Red 28 (Congo red) from aqueous solutions by eggshells: batch and column studies", Sep. Sci. Technol., 2012, vol. 47, pp. 112-123.

37. Y. Al-Degs, M. Khraisheh, S. Allen, and M. Ahmad. "Adsorption characteristics of reactive dyes in columns of activated carbon ", J. Hazard. Mater. 2009, vol. 165, pp. 944-49.

Published By:

Blue Eyes Intelligence Engineering and Sciences Publication

(c) Copyright: All rights reserved.

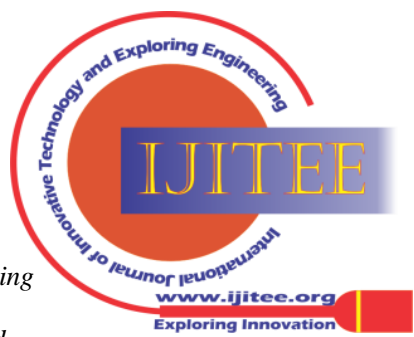


38. S. Sadaf, and H.N. Bhatti. "Evaluation of peanut husk as a novel, low cost biosorbent for the removal of Indosol Orange RSN dye from aqueous solutions: batch and fixed bed studies", Clean Technol. Environ. Policy., 2014, vol. 16,pp. 527-544.

39. W. Li, Q. Yue, P. Tu, Z. Ma, B. Gao, J. Li, and X. Xu. "Adsorption characteristics of dyes in columns of activated carbon prepared from paper mill sewage sludge", Chem. Eng. J., 2011, vol. 178, pp. 197.

\section{AUTHORS PROFILE}

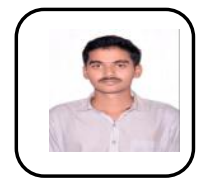

KSGV Manikrishna, is a Mtech Scholar in Dept.. of Chemical Engineering, Andhra University College of Engineering (A), Andhra University. He has done research work in adsorption for batch and column studies using domestic waste as adsorbent. He has significantly ontributed in the field of biosorption. He has published three papers in reputed journals and also participated in more than three international conferences. He is graduated from Andhra University, Visakhapatnam.

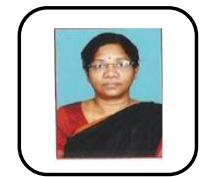

Dr. V.Sridevi, is a Professor from the Dept.. of Chemica Engineering, Andhra University College of Engineering (A), Visakhapatnam, with 15 years of lecturing and also greater than 14 years experience in research. She has made important contributions to the field of Industrial Pollution and Control Engineering, working on bio degradation, bio -reactor design,as well as control of industrial pollution. She has successfully supervised 60 M.Tech students \& $13 \mathrm{Ph}$ D Scholars are pursuing PhDs (05 Awarded).

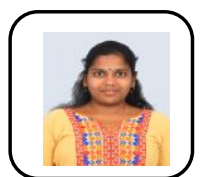

Sri Himaja P, is student doing Post Graduation in Dept. of Chemical Engineering, Andhra University College of Engineering (A), Andhra University. She is working on the project regarding adsorption using household waste.

She had also published papers regarding Biodegradation of toxic and environmental pollutants and harmful effects of Phenolic compounds. She is graduated from Jawaharlal Technological University Kakinada and has served as one of the officers of Society of Petroleum Engineers JNTUK chapter (2017-2018). She has memberships in International Association of Engineers.

Published By: Blue Eyes Intelligence Engineering and Sciences Publication (C) Copyright: All rights reserved. 